\title{
nam \\ DNA-Based Technologies for Grapevine Biodiversity Exploitation: State of the Art and Future Perspectives
}

\author{
Clizia Villano ${ }^{1}$ (D), Riccardo Aiese Cigliano ${ }^{2}$ D , Salvatore Esposito ${ }^{3}$, Vincenzo D'Amelia ${ }^{4}$ (D), Marina Iovene ${ }^{4}$, \\ Domenico Carputo ${ }^{1}$ and Riccardo Aversano ${ }^{1, *(\mathbb{D}}$
}

1 Department of Agricultural Sciences, University of Naples Federico II, Via Università 100, 80055 Portici, Italy; clizia.villano@unina.it (C.V.); carputo@unina.it (D.C.)

2 Sequentia Biotech, Carrer de València, 08009 Barcelona, Spain; raiesecigliano@sequentiabiotech.com

3 CREA Research Centre for Cereal and Industrial Crops (CREA-CI), 71122 Foggia, Italy; salvatore.esposito@crea.gov.it

4 Institute of Biosciences and Bioresources (CNR-IBBR), National Research Council of Italy, Via Università 133, 80055 Portici, Italy; vincenzo.damelia@ibbr.cnr.it (V.D.); marina.iovene@ibbr.cnr.it (M.I.)

* Correspondence: raversan@unina.it; Tel.: +39-081-2532124

check for updates

Citation: Villano, C.; Aiese Cigliano, R.; Esposito, S.; D'Amelia, V.; Iovene, M.; Carputo, D.; Aversano, R. DNA-Based Technologies for Grapevine Biodiversity Exploitation: State of the Art and Future Perspectives. Agronomy 2022, 12, 491. https: / /doi.org/10.3390/agronomy 12020491

Academic Editor: Alain Deloire

Received: 24 January 2022

Accepted: 10 February 2022

Published: 16 February 2022

Publisher's Note: MDPI stays neutral with regard to jurisdictional claims in published maps and institutional affiliations.

Copyright: (C) 2022 by the authors. Licensee MDPI, Basel, Switzerland. This article is an open access article distributed under the terms and conditions of the Creative Commons Attribution (CC BY) license (https:// creativecommons.org/licenses/by/ $4.0 /)$.
Abstract: The cultivated grapevine, Vitis vinifera subsp. vinifera L., is represented by an enormous population of varieties and clones. They arise from the accumulation of gametic and somatic mutations during centuries of sexual and asexual propagation. These varieties represent a vast reservoir of traits/alleles that could be useful in improving the berry quality as well as against environmental stresses. However, most of them are still unexploited. For this reason, an efficient characterization system is essential to define the varietal identity, avoid cases of synonymy (identical genotypes but different names) and homonymy (same names but different genotypes) and deepen our understanding of the existing diversity within the grape germplasm. The plethora of DNAbased high-throughput technologies currently available provides promising tools for the analysis of diversity, overcoming many of the limitations of phenotypic-based diversity analyses. However, the analysis of intra-varietal diversity remains challenging. In this scenario, after summarizing the causes and consequences of grapevine genetic inter- and intra-varietal diversity, we review the DNA-based technologies used for varietal genotyping, emphasizing those able to distinguish clones within a variety. This review provides an update on the technologies used to explore grapevine diversity, the knowledge of which is necessary for an efficient exploitation and conservation of the grapevine germplasm.

Keywords: Vitis; biodiversity; genotyping; molecular markers; DNA-based technologies; NGS

\section{Introduction}

The cultivated grapevine ( $V$. vinifera subsp. vinifera) has a considerable genetic complexity expressed by an enormous varietal diversity. It is estimated that approximately 1200 commercial varieties are grown today solely for wine production (our focus here) [1] Most of them derive from a single seed that probably germinated several centuries ago and have been vegetatively multiplied since that time. Although sexual reproduction led to a great level of variability between varieties (the so-called inter-varietal diversity), spontaneous somatic mutations have further contributed to shape the kaleidoscope of grape diversity that, unlike other crops, is more heterogeneous than its wild relative [2,3]. For centuries, growers have collected and propagated these different selections and labeled them as "clones". Thus, modern varieties consist of groups of different clones with genotypic, morphological, physiological and stress resistance traits slightly different from those of the original mother plant (the so-called intra-varietal diversity). Overall, the existing diversity within the grape germplasm represents an invaluable resource for breeding purposes. In there, it is possible to find traits that affect the fruit (and wine) quality and resistances to 
both biotic and abiotic stresses. For example, Arrizabalaga and collaborators [4] evaluated the effects of an elevated temperature on the development and composition of a set of clones of $V$. vinifera. cv. Tempranillo berries. Their results allowed the selection of two clones with a marked thermal sugar:anthocyanin decoupling that were able to maintain high concentrations of total skin anthocyanins, extractable anthocyanins and color intensity under $28^{\circ} \mathrm{C} / 18^{\circ} \mathrm{C}$. Similarly, Kupe and collaborators [5] identified three clones of Karaerik harvested in the Uzumlu district of Erzincan (Turkey) with a high antioxidant activity, representing a great potential for grape breeders and the food industry as well as health-conscious consumers. Unfortunately, wine market globalization, variety-oriented wine labeling and the increasing demand for healthy plant material have led to a decline of the richness of winegrape varieties [6]; many of the traditional and local cultivars have almost disappeared and several of them are only found in germplasm collections [7]. In this context, it is important to develop and use efficient strategies for the systematic analysis of the diversity of germplasm collections (including, among others, ancient accessions of traditional cultivars and old vineyards).

The assessment of Vitis genetic diversity is routinely carried out using molecular markers. These tools offer innumerable advantages over conventional phenotype-based alternatives. For example, developing a new grape cultivar using traditional breeding techniques takes approximately 25-30 years but the use of genetic markers linked to phenotypes of interest can decrease that time by up to 10 years. Marker-assisted selection (MAS) in grapes offers the greatest potential for traits that are difficult or time-consuming to phenotype such as a few fruit traits that are measurable after several years. The use of MAS in grapevine breeding will not be discussed in the present review because it has been already extensively reviewed $[8,9]$. So far, the applications of molecular techniques to assess $V$. vinifera inter-varietal diversity have shed light on its domestication history [10,11], including the origin of important grapes such as Cabernet Sauvignon [12], Chardonnay [13], Syrah [14], Sangiovese [15], Merlot [16] and Nebbiolo [17]. These studies suggested that the modern European varieties derive from a limited number of distantly related genotypes. In addition, several DNA-based strategies have revealed intra-varietal diversity in grape cultivars such as Chardonnay [18,19]; Sangiovese [20]; Manto Negro, Callet and Moll [21]; Nebbiolo [22]; and Pinot Noir [23], each comprising slightly divergent genotypes. Several reviews have been published regarding the possible origins of grapevine intra-varietal diversity linked to human selection and propagation [24,25]. However, the analysis of intra-varietal diversity remains challenging. Therefore, our knowledge of the extent and impact of this variation on the plant phenotype is still scarce.

Over the last few years, plant research has witnessed tremendous advancement in technology, which has moved from single target analyses to simultaneous assays of multiple targets. This progress has led to the characterization of a massive amount of not only the $V$. vinifera germplasm but also of important related species (e.g., $V$. amurensis, $V$. labrusca, $V$. riparia). Here, after summarizing the current knowledge of the genetic and genomic diversity of the grapevine, we provide a comprehensive overview of the DNA-based technologies used in grape genotyping, emphasizing those that may have a significant impact on grape diversity analyses in the years to come. We discuss the relative merits, pitfalls and cost of each genotyping procedure with the aim of providing a solid reference in the choice of the proper tools, depending on the biological purpose, sample size, desired resolution and available budget.

\section{The Genetic Bases of Grape Inter- and Intra-Varietal Diversity}

At the sequence level, the genetic diversity among varieties and clones consists, typically, of microsatellite DNA or simple sequence repeat (SSR) single nucleotide polymorphisms (SNPs) and small insertions/deletions (InDels). In particular, the polymorphisms at SSR loci arise from the expansion or contraction of the number of repeats by slipped-strand mispairing during DNA replication. SSRs mutate from 10 to 100 thousand times more frequently per generation than SNPs [26]. This is because SSRs are mainly located in 
non-coding regions whereas SNPs are widespread in the whole genome, including the coding regions, and can cause a genic "gain of function". In a grapevine, for example, an SNP found in the coding region of the VvDXS (1-deoxy-D-xylulose-5-phosphate synthase) gene was associated with a floral flavor typical of Muscat varieties and was used to develop a digital PCR-based assay to target allelic variations in the gene [27]. In addition to the small-scale variability, transposable elements (TEs) are a further source of mutations in grapes. TEs may induce changes in single chromosomal sites or in the organization and/or size of the entire genome and have a high potential to alter a plant phenotype. For instance, as reviewed by Milovanov et al. [28], the Gret1 (Grapevine Retrotransposon 1) retroelement played a pivotal role in generating berry color variations in grapevine clones; a transposable element of the hobo, Ac, Tam3 (haT) family caused the multiplication and branching of flower meristems in a clone of Carignan; and the Mila-flb inverted-repeat transposable element was responsible for the fleshless berry (flb) somatic variant in the cultivar Ugni Blanc. Moreover, mounting evidence recognizes a significant role of structural variations (SVs) in making most of the selectable variations in grapevines [29]. SVs include presence/absence variations $(\mathrm{PAV})$, copy number variations (CNVs) and other miscellaneous rearrangements such as inversions, insertions and translocations [30]. These variations often originate from mistakes during DNA replication, repair or recombination processes. Examples of SVs have been described in somatic variants that differ in berry color and ripening time (reviewed in [25,31]). An additional layer of diversity within a species is provided by epigenetic changes such as DNA methylation, histone modification and the action of small RNA molecules. Epimutations associated with phenotypic traits have been described in plants but there are no reports available for grapevines. However, Xie et al. [32] found that epigenetic changes act as a form of memory of the environment of the vineyard that would ultimately contribute to the uniqueness of the clones used for wine production. Therefore, the concepts and techniques of classical and modern germplasm diversity assessments should consider integrating recent progress in epigenetics, initially by identifying their association with phenotypic variations and then by assessing their stability in subsequent generations [33]. In summary, the variability of the grapevine genomes has a very complex matrix comprising different elements that should be explored using the proper tools.

\section{Genetic Technologies for the Characterization of Grape Diversity}

The following section provides an overview of the main genetic techniques used to study the rich genetic diversity of grapes (Figure 1) with the pros and cons of each technology and examples of successful applications in grapevines. We first describe the cytological techniques used to detect large-scale variations through the direct mapping of DNA sequences on the genome. We then approach PCR-based techniques that analyze DNA polymorphisms at single or multiple loci throughout the genome (i.e., SSR or SNPs). Finally, we review high-performance sequencing techniques (NGS, next-generation sequencing) and the chip-based marker platforms that have allowed the identification of thousands of SNPs and high-throughput genotyping [34-36]. 


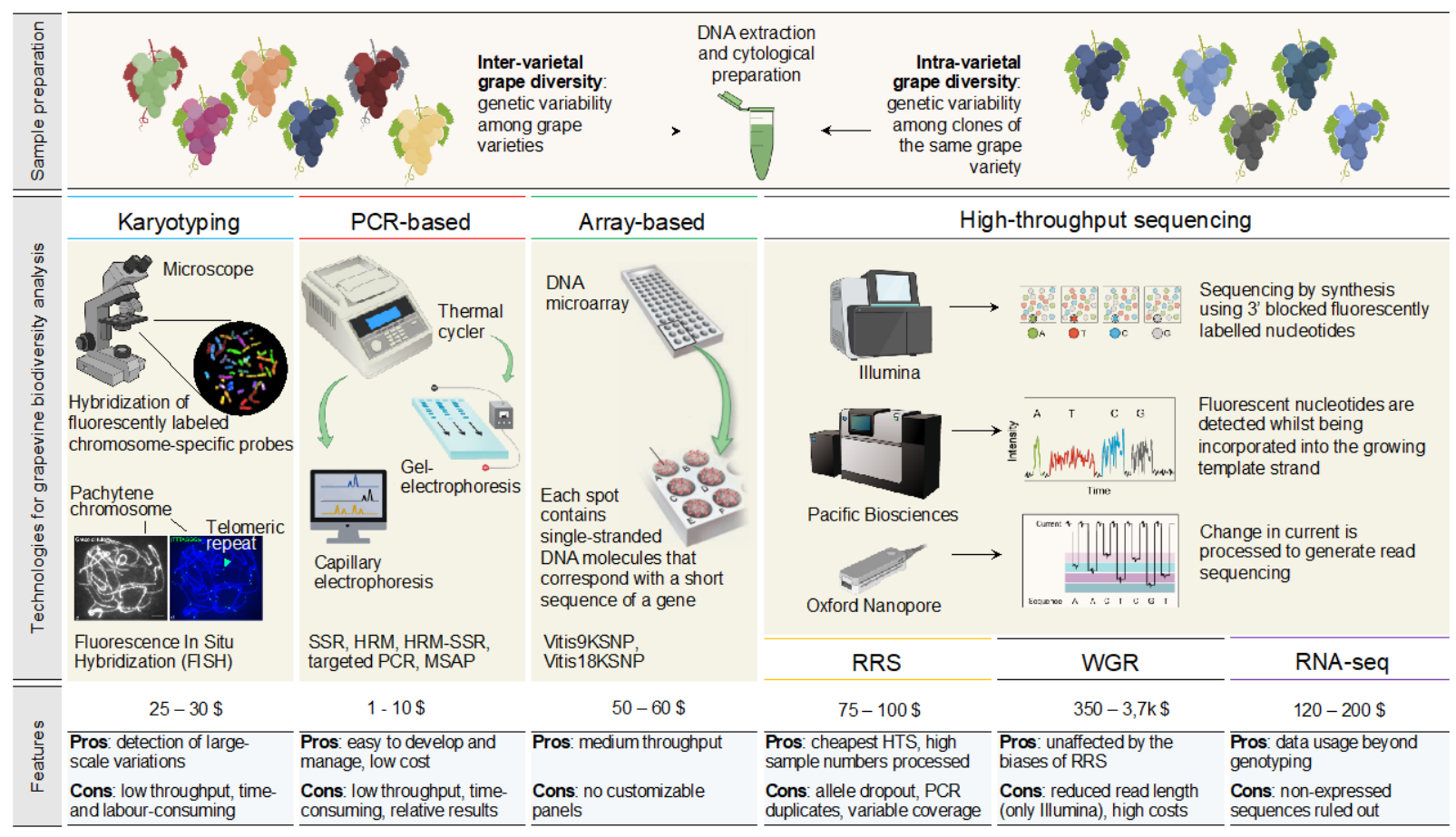

Figure 1. Overview of technologies currently used for analyzing grapevine biodiversity. The discovery of DNA changes between and within varieties is possible, starting from DNA or cytological preparations. The principle, average costs per sample, main advantages and challenges are summarized for each technique.

\subsection{Cytogenetic Techniques}

Among modern cytogenetic tools, fluorescence in situ hybridization (FISH) is the most used in the analysis of the diversity of several crop and model species (Table 1). It has served to identify individual chromosomes, setting the basis for comparative analyses and the detection of large-scale SVs as well as differences in the distribution and/or abundance of specific repeat elements [37-41]. In plants, typical cytological preparations for FISH consist of metaphase chromosomes, interphase nuclei, meiotic pachytene chromosomes and DNA "fibers". On the other hand, repetitive DNA sequences and large insert genomic DNA clones (such as bacterial artificial chromosomes (BACs) and fosmids) have been the most common FISH probes in plants; see Jiang [42] for a review that includes a grapevine, for which only a few studies are available. This is likely because it is difficult to obtain good chromosome preparations from roots or anthers in a grapevine. In addition, a grapevine has a large number of small chromosomes for which there have been no efforts to develop a reliable identification system. Among the few studies available, FISH using ribosomal DNA (rDNA) probes has allowed the identification of four $45 \mathrm{~S}$ rDNA $[43,44]$ and two $5 \mathrm{~S}$ rDNA loci $[43,45,46]$. FISH has also revealed that the retrotransposon Gret1 is inserted in the euchromatic regions of at least half of the grapevine chromosomes [47]. In addition to repetitive sequences, several BAC clones from the Pinot Noir PN40024 library were mapped onto the chromosomes of various grapes to validate large SVs, including duplications and deletions $[48,49]$, or to confirm the diploid state of specific chromosome regions [50]. FISH allows the analysis of only few samples at a time and is considered to be a niche technique. However, it could provide new insights into grape diversity by taking advantage of the development of FISH probes based on synthetic oligos. Oligo-based probes can be designed from repetitive DNA elements such as satellite repeats or from single-copy DNA sequences. Indeed, thanks to the technical advances in DNA synthesis, it is now possible to synthesize FISH probes made of pools of thousands of oligonucleotides, each ca. 40 nucleotides long, which are complementary to single-copy sequences of a specific chromosome or chromosome region $[40,42,51]$ (Table 1 ). With the availability of several chromosome-level 
genome references for grapes, this approach could quickly provide chromosome-specific painting probes for comparative studies in grapevines. Many companies synthesize such oligo-paint libraries and several of them offer a complementary probe design. The cost of the oligo-paint probes mainly depends on the number of oligos (and their length) in the library. An unlabeled oligo-paint library of 20,000-27,000 oligos is approximately 1500 USD plus the cost of the reagents for labeling. However, unlabeled libraries are amplifiable and represent a permanent resource of the designed probe [42]. Labeled, ready-to-use oligo-paint probes are also an option. The cost for a labeled probe of 20,000 oligos is approximately 1800 USD and the amount provided $(700 \mathrm{pmol})$ should be enough for at least 70 hybridizations/slides.

Table 1. Summary of the techniques used for grape clone genotyping. Further details are reported in the text.

\begin{tabular}{|c|c|c|c|c|}
\hline Technique & Full Name & Mutation Types & Principle Involved & Throughput \\
\hline FISH & $\begin{array}{c}\text { Fluorescence In Situ } \\
\text { Hybridization }\end{array}$ & SVs; repeat elements & Hybridization & Low \\
\hline SSR & Simple Sequence Repeat & Repeat elements & $\begin{array}{l}\text { PCR; capillary } \\
\text { electrophoresis }\end{array}$ & Low \\
\hline SSR-HRM & $\begin{array}{c}\text { Microsatellite } \\
\text { High-Resolution Melting }\end{array}$ & Repeat elements & Real-time PCR & Low \\
\hline MSAP & $\begin{array}{l}\text { Methylation-Sensitive } \\
\text { Amplified Polymorphism }\end{array}$ & Epialleles & $\begin{array}{l}\text { PCR; capillary } \\
\text { electrophoresis }\end{array}$ & Low \\
\hline HRM & High-Resolution Melting & SNPs & Real-time PCR & Low \\
\hline Targeted PCR & - & SNPs & PCR & Low \\
\hline $\begin{array}{l}\text { Vitis9KSNP and } \\
\text { Vitis18KSNP }\end{array}$ & - & SNPs & Hybridization & Medium \\
\hline GBS & Genotyping By Sequencing & SNPs & $\begin{array}{c}\text { Digestion; } \\
\text { hybridization }\end{array}$ & High \\
\hline RRS & $\begin{array}{l}\text { Reduced Representation } \\
\text { Sequencing }\end{array}$ & SNPs; InDels & $\begin{array}{c}\text { Digestion; } \\
\text { hybridization }\end{array}$ & High \\
\hline WGR & $\begin{array}{l}\text { Whole Genome } \\
\text { Resequencing }\end{array}$ & All & NGS & High \\
\hline
\end{tabular}

\subsection{PCR-Based Techniques}

The first revolution in grape molecular genetics took place with the advent of the first PCR-based markers such as RAPD (Random Amplified Polymorphic DNA) and I-SSR (inter-simple sequence repeats). These markers were successfully employed for the molecular characterization of different grape varieties [52,53]. However, due to their known limitations, RAPD and I-SSR have been rapidly replaced by SSRs and SNPs (see below) (Table 1). The genome of grape varieties is marked by different SSR patterns that have been used to reveal the pedigree of several varieties $[54,55]$ and their historical origins $[12,13,16,55,56]$ since the 1990s. SSRs have revealed unexpected synonyms [57-59] also in grape varieties from distant geographical areas, as in the case of Malvasia delle Lipari, Malvasia di Sardegna, Greco di Gerace (Italy), Malvasia de Sitges (Spain) and Malvasia dubrovačka (Croatia) [60]. Owing to their extensive use worldwide, large international Vitis databases containing SSR profiles are now available as references for cultivar identification (http:/ / www.eu-vitis.de/index.php (accessed on 23 January 2022); http:/ / www.vivc.de (accessed on 23 January 2022)). To standardize the molecular analysis protocols, a set of nine SSRs has been established as a reference kit for grapevine genotyping $[58,59]$ and several public Vitis databases have been established, including the European [61], Greek [62], Swiss [63] and Italian [64] Vitis databases. Interestingly, Kim et al. [65] developed a set of 21 SSR markers suitable for amplifying both vinifera and non-vinifera species and, therefore, universal candidate markers for cross-species genotyping. However, SSR genotyping is subject to technical variations and thus it requires precise calibration based on the reference cultivars before comparisons can be made between laboratories [66]. An interesting and 
powerful upgrade of the standard SSR technique is the SSR-HRM (high-resolution melting). It is a post-PCR method in which the amplicon sequences are denatured and the pattern of fluorescence lessens due to the release of an intercalating dye that is monitored $[67,68]$. The outputs of the data are melting (dissociation) curves that plot the reduction in fluorescence against the increase in temperature. SSRs in amplicon sequences can result in different melting curves. Despite the efficiency of this technique, few applications have been reported for grapevine discrimination due to the complicated necessity of having a good positive control [69-71]. Regarding the PCR-based tools dedicated to epigenome profiling, MSAP (methylation-sensitive amplified polymorphism) [72] markers are the most popular although scantily applied to grapevines. This method relies on the use of restriction enzyme isoschizomers that recognize the same DNA sequence (CCGG) but are differentially sensitive to cytosine methylation. In $V$. vinifera, Ocaña et al. [72] discriminated 37 out of 40 Pinot Noir clones using 9 MSAP primer combinations. This is the only example of MSAP applications for grape fingerprinting, probably because of the time and intensive labor required to set up and apply it.

Regarding the costs, there are many microsatellite genotyping service providers but none for SSR-HRM and MSAP analyses, probably because SSR markers are preferred for their simplicity and suitability for large-scale automation. The charges for SSR genotyping depend on the level of multiplexing and the size of the assay. A survey of service providers indicated that, on average, the cost per sample was approximately 10 USD, including DNA extraction and quantification as well as PCR amplification and a capillary electrophoresis run (personal communications). In the past, alternative strategies have been developed to reduce the genotyping costs such as the use of SSR primers modified by a 19 bp extension at the $5^{\prime}$ end identical to the M13 nucleotide sequence (M13-tailed primer). This method allows multiplexing sequencing reactions of amplicons obtained using the M13 primer (reverse) conjugated with a fluorophore and various modified SSRs (forward) [73]. Regarding the SSR-HRM and MSAP, the cost per data point fell below 1 USD for combinations involving 10 or more markers and sample sizes above 100 . Such estimations were calculated assuming a conservative pricing for reagents. However, costs can undergo variations based on laboratory protocols and can be significantly lower with the purchase of large amounts of reagents at reduced prices.

\subsection{Array-Based Technologies}

The use of SNP molecular markers to study diversity in life has progressively increased over the last few years. The reason why is linked to the high number of point mutations and their generally low mutation rate, which make SNPs effective tools for germplasm identification. Thanks to their use, it has been possible to determine the first-degree relationships between numerous vine varieties [74,75]. Although SNPs can be detected through gel-based profiling, advances in array hybridization techniques have greatly facilitated genetic diversity analyses at a high resolution. In plants, SNP arrays (a compilation of thousands or even millions of polymorphic sites that allow the genotyping of many samples at multiple loci simultaneously and at a low cost) have been developed primarily in species for which large amounts of genomic data are already available such as Vitis (Table 1).

The first SNP array for grapevines, the Illumina Vitis9KSNP chip, was developed in 2010 by Sean Myles and collaborators and contained 9000 SNPs identified in 11 varieties of $V$. vinifera and 6 wild Vitis species. In 2013, thanks to the availability of sequencing data produced by the GrapeReSeq consortium, a new Illumina array (Vitis18KSNP) containing approximately 18,000 SNP loci was produced by Marie-Christine Le Paslier from 47 varieties of $V$. vinifera, 12 species of Vitis and 5 of Muscadinia rotundifolia. This array has been used to genotype many cultivated and wild accessions with different geographic origins [76-78]. The limitations of SNP arrays (Illumina Vitis9KSNP and Vitis18KSNP arrays) fall back on the use of the same panel of SNPs across all experiments and all germplasms as well as on the specificity of the hybridization between the sequences that are allocated on the support (probes) and those of the genotyped samples, which often differ significantly from them 
because they are distant from the reference genome on which the probes were designed. Several factors contribute to reducing the hybridization, including the presence of indels, CNVs and transposons. The average price to obtain 18.071 markers is approximately 60 USD per sample, which includes library preparation and sequencing; however, this is subject to fluctuations over time and is volume-dependent (personal communications).

\subsection{High-Throughput Sequencing (HTS) Technologies}

As reported above, there are several limitations to genotyping grapevines using conventional gel-based approaches such as a low genome representation, technical variations between assays, the need for relative allele size values that are standardized across laboratories, manual sizing and processing and the necessity of having a good positive control as well as, in a few cases, a lack of suitability for large-scale automation [79]. Recent advances in DNA sequencing have revolutionized the field of genomics, allowing a high-throughput identification of markers at low costs. HTS systems are already used in Vitis genotyping such as genotyping by sequencing (GBS), which includes several reduced representation sequencing (RRS) approaches and a whole genome resequencing (WGR) strategy [80,81]. Here, we provide an account of RRS and WGR methods that have enabled the measurement of genetic diversity in grapevines (Table 1 and Figure 1). In addition, we propose the use of RNA-seq as a cost-effective alternative for genotyping.

\subsubsection{Reduced Representation Sequencing (RRS)}

Reduced representation strategies leverage the massive sequencing of a small portion of the genome to obtain a representative picture of a given sample and rapidly detect DNA polymorphisms. The earliest RRS method, restriction site-associated DNA (RAD) sequencing [82], used restriction endonucleases to cleave the genome into fragments. In this and similar methods, each sample is assigned a unique barcoded adapter for multiplexed sequencing in a single flow cell lane, enabling a cost reduction per analysis. RRS remains the method of choice for biological diversity applications in which prior genomic information is unavailable. NGS sequences (reads) can be processed bioinformatically to first cluster them into loci and then identify polymorphisms across the samples even if a reference genome is not available. This method is implemented in the STACKS pipeline [83], which is widely used to analyze RRS data. In addition, RRS data can be used to genotype species with an available reference genome by performing a standard variant calling analysis whereby the reads are first mapped onto the reference genome and then the SNPs and InDels are identified with specific algorithms, including Freebayes [84], Platypus [85] or GATK [86]. This technique has been used for genotyping wild and cultivated grapevines $[87,88]$. In addition to RADSeq, another innovative and cost-effective RRS method is the genotyping by sequencing (GBS) technique developed by Elshire et al. [89], which has been applied to several species, including Vitis [90-94]. It employs restriction enzymes and the next-generation sequencing of genomic libraries for de novo genotyping of SNPs. With this approach, Calderon et al. [94] distinguished 14 different clonal genotypes within the Malbec cultivar. RRS approaches do not require the preselection of regions to be interrogated but need extensive sequencing. The three main pitfalls of RRS are allele dropout, PCR duplicates and a variance in coverage. In allele dropout, the sequence variations in the restriction enzyme recognition site prevent cutting and can thus lead to genotyping problems [95]. Random PCR duplication during the library preparation can also result in a mismatch between the ratio of the PCR product allele and the original amount of starting DNA of each allele. Finally, a variance in coverage between the loci can be caused by an amplification bias toward fragments of a shorter length with a higher GC content. In addition to the potential biases introduced during the sample preparation and sequencing, it is also worth noting that the choice of the bioinformatic pipelines used to analyze the samples can have a huge impact on the final results and conclusions [96].

Costs differ by methods and can undergo rapid changes. Many sequencing providers calculate the price for RRS sequencing based on the average number of expected sequenced 
markers. The average price to obtain approximately 30,000 markers ranges from 75 to 100 USD per sample, which also includes DNA quality control and normalization, library preparation and sequencing and a bioinformatics analysis (source https://genohub.com/ (accessed on 23 January 2022) and personal communications).

\subsubsection{Whole Genome Resequencing Approaches}

The use of WGR approaches in grapes started to increase in 2007 in concomitance with the release of the first grape draft genome (referred to as the $8 \mathrm{X}$ genome) from a highly homozygous accession (Pinot Noir, PN40024) and a highly heterozygous grapevine clone (Pinot Noir, ENTAV115) [97,98]. Four years later, Adam-Blondon et al. [99] released an improved version of the PN40024 genome (12X.v0), which was recently improved (12X.v2) by a deeper gene annotation [100]. The availability of these resources paved the way to resequence many individuals and delineate the inter- and intra-species genetic variations across the Vitaceae family [101]. In addition, it also facilitated large-scale genotyping through NGS technologies at the clonal level, which is often not possible by using molecular markers, even those belonging to different classes, as highlighted by several authors for both SSRs and SNPs [35,102]. Nowadays, a few reports have been published on the use of WGR approaches to characterize the extent of somaclonal variations that accumulate at the genome level within given cultivars $[22,25,103]$. These have exploited the sequencing by synthesis approach, an NGS method that detects the light emitted when nucleotides are incorporated by a DNA polymerase in a strand complementary to the clonally amplified and spatially separated DNA templates [104]. These so-called second-generation sequencing technologies (among the available ones, Illumina and Roche 454) have been used in grapes and are powerful at detecting DNA variations due to their capacity to generate millions of sequences at once. Carrier et al. [25] paved the way by comparing three Pinot Noir clones (PN386, PN583 and PN777) with each other as well as against the available sequences of the ENTAV115 and PN40024 reference genomes using 454 GS-FLX sequencing technology. They found that TEs represented the most substantial proportion of the somatic mutation types affecting those clones. Subsequently, Carbonell-Bejerano et al. [103] used Illumina short-read sequencing to characterize the somatic mutations that led to white berries in the Tempranillo cultivar, highlighting a catastrophic genome rearrangement that caused the hemizygous deletion of 313 genes. In the same year, Gambino et al. [22] resequenced the whole genomes of three phenotypically divergent clones of the Italian wine cultivar Nebbiolo (CVT71, CVT423 and CVT185), exploiting an Illumina short-read sequencing technology. They identified $12.886,7.914$ and 8.070 putative clone-specific SNVs, respectively.

However, NGS technologies also have drawbacks. First, the reduced read length (from $35 \mathrm{bp}$ to $450 \mathrm{bp}$, considering different technologies) can limit the accuracy of the analysis in highly repetitive genomes as well as in genomic regions with a higher repetitive content due to mapping errors. In addition, a limited read length leads to a lower accuracy in the detection of large genomic variants, i.e., structural variants (SVs) with respect to short InDels and SNPs [105]. Second, the library preparation can introduce biases linked to the GC content of the DNA fragments, leading to uneven coverage distribution with regions with higher coverage and others without reads [106].

Thanks to the development of third-generation sequencing (TGS) platforms, it is now possible to produce reads spanning tens or hundreds of kilobase pairs (kbp), which can be used to perform an in-depth analysis of SVs. Among the TGS technologies, Pacific Bioscience (PacBio) uses a single molecule real-time sequencing (SMRT) approach in which a DNA polymerase/template complex is physically bound on a chip and fluorescently labeled nucleotides are detected as they are inserted into the replicating strand [107], allowing the production of reads up to $40 \mathrm{kbp}$ on average. On the other hand, Oxford Nanopore TGS technology does not rely on DNA synthesis because the DNA molecules pass through a nanopore that is surrounded by an electrolyte solution and the bases are identified by detecting the changes in the conductivity induced by the different nucleotides [108]. In 2016, 
Chin and colleagues [109] generated a new reference sequence for the heterozygous cultivar Cabernet Sauvignon by combining SMRT technology and FALCON, a new diploid-aware long-read assembler, to assemble haplotype contigs or 'haplotigs' that represented the diploid genome with correctly phased homologous chromosomes. The assembly produced was significantly more contiguous (contig N50 $=2.17 \mathrm{Mb}$ ) compared with the original PN40024 assembly (contig N50 $=102.7 \mathrm{kbp}$ ) and provided the first phased sequences of the diploid V. vinifera genome (for a review, see [110]). In 2018, Roach and collaborators [111] released a high-quality diploid-phased Chardonnay genome assembly using a combination of PacBio and Illumina sequencing. Due to the use of stringent filters, they identified a small set of fewer than $2 \mathrm{k}$ markers able to distinguish Chardonnay clones. Recently, Vondras et al. [19] showed the results obtained from PacBio whole genome sequencing of 15 Zinfandel clones and confirmed the results of Carrier et al. [25] in which the intergenic space drove the clonal diversification. They also demonstrated that asexually propagated plants accumulate deleterious mutations mainly in their introns and intergenic space. Two main limitations affect the use of TGS for large-scale genotyping; a higher cost compared with Illumina and a higher sequencing error rate. PacBio and nanopore technologies can have a base error rate varying from $10 \%$ to $20 \%$, respectively, against an average Illumina error rate of $0.1 \%$ [111], which limits their application in the analysis of small variants, especially in repetitive regions.

As with RRS, the costs of WGR change rapidly, varying with genome size, laboratory location, sequencing specifications and machines. Considering an average coverage of $30 \times$ per sample, the cost for a library preparation and Illumina paired-end $150 \mathrm{bp}$ sequencing on a NovaSeq 6000 could range from 300 to 550 USD per sample (source https://genohub.com/ (accessed on 23 January 2022) and personal communications). In order to achieve the same coverage with PacBio (SMRT $20 \mathrm{kbp}$ library preparation and two flow cells of Sequel I), an approximate cost of 3700 USD would be required (personal communication). Regarding nanopore technology, a library preparation and sequencing at a target coverage of $30 \times$ with a MinION machine could have an approximate cost of 550 USD per sample (excluding the markup of the sequencing companies; https://nanoporetech.com/products/comparison (accessed on 23 January 2022)). Although WGR is, therefore, still cost-prohibitive for smaller laboratories, it also benefits from being mostly unaffected by the biases of RRS.

\subsubsection{RNA Sequencing}

RNA sequencing is a technology that allows the sequencing of the mRNA or total RNA fraction of any given sample and it can be performed with any second- or third-generation sequencing technology. The most frequent application of RNA-seq is the expression profiling of the genes in tissues or genotypes of interest and, at the moment of this review, approximately 200 papers have been published in which RNA-seq has been applied to Vitis vinifera to study different aspects of the plant biology, including bud development [112-114], berry development and ripening [115-117] and the response to disease or pathogens [118-120]. By combining TGS technologies and RNA-seq, Minio et al. [116] investigated expressed gene isoforms (Iso-Seq) during berry ripening. The new approach allowed the authors to capture the entire gene space of a plant and build a comprehensive reference for transcriptional profiling even without a pre-defined reference genome. Comparing the new gene space with other cultivars, the authors suggested that the transcriptome built with Iso-Seq represented most of the expressed genes in the grape berries, including 1501 cultivarspecific genes. In recent years, RNA-seq has become increasingly used in human studies as a tool to identify small genomic variants such as SNPs and InDels [121,122]. In grapes, there are only a few examples of RNA-seq-based variant calling. Royo et al. [123], using a combination of quantitative genetics, fine mapping, RNA-seq differential expression analyses and variant calling, were able to identify the causal mutation of the seedlessness phenotype of the seed development inhibitor (sdi) mutant, which appeared to be an Arg197Leu substitution in the seed morphogenesis regulator gene AGAMOUS-LIKE 11 (VviAGL11). 
Zenoni et al. [124], by comparing Pinot Noir 40024 and Corvina using RNA-seq data, identified more than 85,000 variants in the coding regions, introns and unannotated regions. Royo et al. [125] used RNA-seq variant calling to identify 14 variants in Corinto Bianco, a parthenocarpic somatic variant of the seeded cultivar Pedro Ximenes. It is also intriguing that, at the moment of this review, more than 6000 Vitis vinifera RNA-seq samples have been deposited in the Sequence Read Archive (NCBI), representing an incredible source of genetic information that could be accessed at virtually no cost beside the computational costs required to perform the variant calling.

Using RNA-seq data to perform variant calling can have several clear advantages and disadvantages compared with RRS and WGR. The first advantage is that RNA-seq data come with intrinsic information regarding the gene expression in the samples, which can be used to address multiple biological questions in addition to the identification of variants. Due to the nature of RRS protocols, the distribution of the variants in the genome is random, depending on the distribution of the restriction sites in the genome of the sample and the efficiency of the digestion. As a consequence, most of the variants are located in intergenic regions, reducing the possibility of associating traits with specific genes. On the other hand, RNA-seq variants can be derived from coding- and non-coding-expressed genes, thus providing not only enough information for genotyping but also to perform association studies [126]. Compared with WGR, RNA-seq has the limitation of focusing only on the expressed genes. Additional limitations of the use of RNA-seq data for variant calling are due to more complicated bioinformatics processing. Specific pipelines must be used to reduce possible false positives resulting from mapping errors induced by splicing events, RNA editing and allele-specific expressions [127,128].

In terms of costs, RNA-seq is a cheaper alternative to WGR but it is generally more expensive than RRS techniques. The actual cost per sample depends on the library choice, i.e., mRNA-seq vs. Total RNA-seq (with rRNA depletion), sequencing technology and the number and length of the reads. An mRNA-seq performed with an Illumina NovaSeq 6000 producing $15 \mathrm{M}$ of fragments ( $30 \mathrm{M}$ of paired-end reads) can have a cost ranging from 120 to 200 USD (source https:/ / genohub.com/ (accessed on 23 January 2022) and personal communications) with the cost approximately doubling for a Total RNA-seq.

\section{Conclusions}

The present review provides an update on the technologies used to explore grapevine diversity, the knowledge of which is necessary for an efficient exploitation and conservation of the grapevine germplasm. The rapid diffusion of high-throughput sequencing technologies is transforming our way of accessing biodiversity. However, the traditional molecular technologies should not be summarily discarded. Indeed, each approach provides results with a different resolution and accuracy and has different potentials for multiplexing and a high-throughput. Therefore, the choice of the proper genotyping tool should consider the biological purpose, sample size, desired resolution and accuracy as well as the budget available.

Author Contributions: Conceptualization: C.V. and R.A.; writing-original draft preparation: C.V.; writing-review and editing: R.A.C., V.D., S.E., M.I. and D.C.; supervision: R.A. All authors have read and agreed to the published version of the manuscript.

Funding: This research received no external funding.

Acknowledgments: We are grateful to Alessia Gallucci (University of Naples Federico II) for her technical support.

Conflicts of Interest: The authors declare no conflict of interest. 


\section{References}

1. Lacombe, T.; Audeguin, L.; Boselli, M.; Bucchetti, B.; Cabello, F.; Chatelet, P.; Crespan, M.; D’Onofrio, C.; Eiras Dias, J.; Ercisli, S.; et al. Grapevine European catalogue: Towards a comprehensive list. Vitis 2011, 50, 65-68.

2. Aradhya, M.K.; Dangl, G.S.; Prins, B.H.; Boursiquot, J.-M.; Walker, M.A.; Meredith, C.P.; Simon, C.J. Genetic Structure and Differentiation in Cultivated Grape, Vitis vinifera L. Genet. Res. 2003, 81, 179-192. [CrossRef] [PubMed]

3. Salmaso, M.; Faes, G.; Segala, C.; Stefanini, M.; Salakhutdinov, I.; Zyprian, E.; Toepfer, R.; Grando, M.S.; Velasco, R. Genome Diversity and Gene Haplotypes in the Grapevine (Vitis vinifera L.), as Revealed by Single Nucleotide Polymorphisms. Mol. Breed. 2005, 14, 385-395. [CrossRef]

4. Arrizabalaga, M.; Morales, F.; Oyarzun, M.; Delrot, S.; Gomès, E.; Irigoyen, J.J.; Hilbert, G.; Pascual, I. Tempranillo Clones Differ in the Response of Berry Sugar and Anthocyanin Accumulation to Elevated Temperature. Plant Sci. 2018, 267, 74-83. [CrossRef]

5. Kupe, M.; Karatas, N.; Unal, M.S.; Ercisli, S.; Baron, M.; Sochor, J. Phenolic Composition and Antioxidant Activity of Peel, Pulp and Seed Extracts of Different Clones of the Turkish Grape Cultivar 'Karaerik'. Plants 2021, 10, 2154. [CrossRef]

6. Wolkovich, E.M.; García de Cortázar-Atauri, I.; Morales-Castilla, I.; Nicholas, K.A.; Lacombe, T. From Pinot to Xinomavro in the World's Future Wine-Growing Regions. Nat. Clim. Chang. 2018, 8, 29-37. [CrossRef]

7. This, P.; Lacombe, T.; Thomas, M.R. Historical Origins and Genetic Diversity of Wine Grapes. TRENDS Genet. 2006, 22, 511-519. [CrossRef]

8. Bošković, J. Influence of Genetic Variability of Grapes to Produce High-Quality Wines. J. Agron. Technol. Eng. Manag. 2020, 3, $483-488$.

9. Riaz, A.; Anjum, M.A.; Naz, S.; Balal, R.M. Applications of Molecular Markers in Fruit Crops for Breeding Programs-A Review. Phyton 2021, 90, 17 .

10. Myles, S.; Boyko, A.R.; Owens, C.L.; Brown, P.J.; Grassi, F.; Aradhya, M.K.; Prins, B.; Reynolds, A.; Chia, J.-M.; Ware, D. Genetic Structure and Domestication History of the Grape. Proc. Natl. Acad. Sci. USA 2011, 108, 3530-3535. [CrossRef]

11. Bacilieri, R.; Lacombe, T.; Le Cunff, L.; Di Vecchi-Staraz, M.; Laucou, V.; Genna, B.; Péros, J.-P.; This, P.; Boursiquot, J.-M. Genetic Structure in Cultivated Grapevines Is Linked to Geography and Human Selection. BMC Plant Biol. 2013, 13, 25. [CrossRef]

12. Bowers, J.E.; Meredith, C.P. The Parentage of a Classic Wine Grape, Cabernet Sauvignon. Nat. Genet. 1997, 16, 84-87. [CrossRef]

13. Bowers, J.; Boursiquot, J.-M.; This, P.; Chu, K.; Johansson, H.; Meredith, C. Historical Genetics: The Parentage of Chardonnay, Gamay, and Other Wine Grapes of Northeastern France. Science 1999, 285, 1562-1565. [CrossRef]

14. Bowers, J.E.; Siret, R.; Meredith, C.P.; This, P.; Boursiquot, J.-M. A Single Pair of Parents Proposed for a Group of Grapevine Varieties in Northeastern France. Acta Hort. 1998, 528, 129-132. [CrossRef]

15. Vouillamoz, J.; Monaco, A.; Costantini, L.; Stefanini, M.; Scienza, A.; Grando, M.S. The Parentage of 'Sangiovese', the Most Important Italian Wine Grape. Vitis 2007, 46, 19-22.

16. Boursiquot, J.-M.; Lacombe, T.; Laucou, V.; Julliard, S.; Perrin, F.-X.; Lanier, N.; Legrand, D.; Meredith, C.; This, P. Parentage of Merlot and Related Winegrape Cultivars of Southwestern France: Discovery of the Missing Link. Aust. J. Grape Wine Res. 2009, 15, 144-155. [CrossRef]

17. Raimondi, S.; Tumino, G.; Ruffa, P.; Boccacci, P.; Gambino, G.; Schneider, A. DNA-Based Genealogy Reconstruction of Nebbiolo, Barbera and Other Ancient Grapevine Cultivars from Northwestern Italy. Sci. Rep. 2020, 10, 1-16. [CrossRef]

18. Riaz, S.; Garrison, K.E.; Dangl, G.S.; Boursiquot, J.-M.; Meredith, C.P. Genetic Divergence and Chimerism within Ancient Asexually Propagated Winegrape Cultivars. J. Am. Soc. Hortic. Sci. 2002, 127, 508-514. [CrossRef]

19. Vondras, A.M.; Minio, A.; Blanco-Ulate, B.; Figueroa-Balderas, R.; Penn, M.A.; Zhou, Y.; Seymour, D.; Ye, Z.; Liang, D.; Espinoza, L.K. The Genomic Diversification of Grapevine Clones. BMC Genom. 2019, 20, 1-19. [CrossRef]

20. Vignani, R.; Bowers, J.E.; Meredith, C.P. Microsatellite DNA Polymorphism Analysis of Clones of Vitis vinifera 'Sangiovese'. Sci. Hortic. 1996, 65, 163-169. [CrossRef]

21. Cretazzo, E.; Meneghetti, S.; De Andrés, M.T.; Gaforio, L.; Frare, E.; Cifre, J. Clone Differentiation and Varietal Identification by Means of SSR, AFLP, SAMPL and M-AFLP in Order to Assess the Clonal Selection of Grapevine: The Case Study of Manto Negro, Callet and Moll, Autochthonous Cultivars of Majorca. Ann. Appl. Biol. 2010, 157, 213-227. [CrossRef]

22. Gambino, G.; Dal Molin, A.; Boccacci, P.; Minio, A.; Chitarra, W.; Avanzato, C.G.; Tononi, P.; Perrone, I.; Raimondi, S.; Schneider, A Whole-Genome Sequencing and SNV Genotyping of 'Nebbiolo' (Vitis vinifera L.) Clones. Sci. Rep. 2017, 7, 1-15. [CrossRef]

23. Carrier, G.; Le Cunff, L.; Dereeper, A.; Legrand, D.; Sabot, F.; Bouchez, O.; Audeguin, L.; Boursiquot, J.-M.; This, P. Transposable Elements Are a Major Cause of Somatic Polymorphism in Vitis vinifera L. PLoS ONE 2012, 7, e32973. [CrossRef]

24. Pelsy, F. Molecular and cellular mechanisms of diversity within grapevine varieties. Heredity 2010, 104, 331-340. [CrossRef] [PubMed]

25. Carbonell-Bejerano, P.; Royo, C.; Mauri, N.; Ibáñez, J.; Zapater, J.M.M. Somatic variation and cultivar innovation in grapevine. In Advances in Grape and Wine Biotechnology; IntechOpen: London, UK, 2019.

26. Guichoux, E.; Lagache, L.; Wagner, S.; Chaumeil, P.; Léger, P.; Lepais, O.; Lepoittevin, C.; Malausa, T.; Revardel, E.; Salin, F. Current Trends in Microsatellite Genotyping. Mol. Ecol. Resour. 2011, 11, 591-611. [CrossRef]

27. Morcia, C.; Tumino, G.; Raimondi, S.; Schneider, A.; Terzi, V. Muscat Flavor in Grapevine: A Digital PCR Assay to Track Allelic Variation in VvDXS Gene. Genes 2021, 12, 747. [CrossRef]

28. Milovanov, A.V.; Tello, J.; Anhalt, U.C.M.; Forneck, A. Truncated Non-Nuclear Transposable Elements in Grapevine: A Mini Review. Sci. Agric. Bohem. 2019, 50, 219-227. [CrossRef] 
29. Zhou, Y.; Muyle, A.; Gaut, B.S. Evolutionary Genomics and the Domestication of Grapes. In The Grape Genome; Springer: Berlin/Heidelberg, Germany, 2019; pp. 39-55.

30. Wellenreuther, M.; Mérot, C.; Berdan, E.; Bernatchez, L. Going beyond SNPs: The Role of Structural Genomic Variants in Adaptive Evolution and Species Diversification. Mol. Ecol. 2019, 28, 1203-1209. [CrossRef]

31. Xu, L.L. Functional Analysis of Grapevine STS7 and STS22 Promoters; MSU Graduate Theses 2981; Missouri State: Springfield, MO, USA, 2016

32. Xie, H.; Konate, M.; Sai, N.; Tesfamicael, K.G.; Cavagnaro, T.; Gilliham, M.; Breen, J.; Metcalfe, A.; Stephen, J.R.; De Bei, R. Global DNA Methylation Patterns Can Play a Role in Defining Terroir in Grapevine (Vitis vinifera Cv. Shiraz). Front. Plant Sci. 2017, 8, 1860. [CrossRef]

33. Springer, N.M.; Schmitz, R.J. Exploiting Induced and Natural Epigenetic Variation for Crop Improvement. Nat. Rev. Genet. 2017, 18, 563-575. [CrossRef]

34. McCue, M.E.; Bannasch, D.L.; Petersen, J.L.; Gurr, J.; Bailey, E.; Binns, M.M.; Distl, O.; Guérin, G.; Hasegawa, T.; Hill, E.W. A High Density SNP Array for the Domestic Horse and Extant Perissodactyla: Utility for Association Mapping, Genetic Diversity, and Phylogeny Studies. PLoS Genet. 2012, 8, e1002451. [CrossRef] [PubMed]

35. Mercati, F.; De Lorenzis, G.; Brancadoro, L.; Lupini, A.; Abenavoli, M.R.; Barbagallo, M.G.; Di Lorenzo, R.; Scienza, A.; Sunseri, F High-Throughput 18K SNP Array to Assess Genetic Variability of the Main Grapevine Cultivars from Sicily. Tree Genet. Genomes 2016, 12, 1-15. [CrossRef]

36. Ruffa, P.; Raimondi, S.; Boccacci, P.; Abbà, S.; Schneider, A. The Key Role of "Moscato Bianco" and "Malvasia Aromatica Di Parma" in the Parentage of Traditional Aromatic Grape Varieties. Tree Genet. Genomes 2016, 12, 50. [CrossRef]

37. Kato, A.; Lamb, J.C.; Birchler, J.A. Chromosome Painting Using Repetitive DNA Sequences as Probes for Somatic Chromosome Identification in Maize. Proc. Natl. Acad. Sci. USA 2004, 101, 13554-13559. [CrossRef]

38. Iovene, M.; Zhang, T.; Lou, Q.; Buell, C.R.; Jiang, J. Copy Number Variation in Potato-An Asexually Propagated Autotetraploid Species. Plant J. 2013, 75, 80-89. [CrossRef] [PubMed]

39. Fransz, P.; Linc, G.; Lee, C.-R.; Aflitos, S.A.; Lasky, J.R.; Toomajian, C.; Ali, H.; Peters, J.; van Dam, P.; Ji, X. Molecular, Genetic and Evolutionary Analysis of a Paracentric Inversion in Arabidopsis Thaliana. Plant J. 2016, 88, 159-178. [CrossRef]

40. do Vale Martins, L.; Yu, F.; Zhao, H.; Dennison, T.; Lauter, N.; Wang, H.; Deng, Z.; Thompson, A.; Semrau, K.; Rouillard, J.-M. Meiotic Crossovers Characterized by Haplotype-Specific Chromosome Painting in Maize. Nat. Commun. 2019, 10, 4604. [CrossRef]

41. Huang, Y.; Huang, W.; Meng, Z.; Braz, G.T.; Li, Y.; Wang, K.; Wang, H.; Lai, J.; Jiang, J.; Dong, Z.; et al. Megabase-scale presence-absence variation with Tripsacum origin was under selection during maize domestication and adaptation. Genome Biol. 2021, 22, 237. [CrossRef]

42. Jiang, J. Fluorescence in Situ Hybridization in Plants: Recent Developments and Future Applications. Chromosome Res. 2019, 27, 153-165. [CrossRef]

43. Haas, H.U.; Alleweldt, G. The Karyotype of Grapevine (Vitis vinifera L.). Acta Hortic. 1998, 528, 249-258. [CrossRef]

44. Castro, C.; Carvalho, A.; Pavia, I.; Leal, F.; Moutinho-Pereira, J.; Lima-Brito, J. Nucleolar Activity and Physical Location of Ribosomal DNA Loci in Vitis Vinifera L. by Silver Staining and Sequential FISH. Sci. Hortic. 2018, 232, 57-62. [CrossRef]

45. Pereira, H.S.; Barão, A.; Delgado, M.; Morais-Cecílio, L.; Viegas, W. Genomic Analysis of Grapevine Retrotransposon 1 (Gret1) in Vitis vinifera. Theor. Appl. Genet. 2005, 111, 871-878. [CrossRef]

46. Falistocco, E.; Passeri, V.; Marconi, G. Investigations of 5S RDNA of Vitis Vinifera L.: Sequence Analysis and Physical Mapping. Genome 2007, 50, 927-938. [CrossRef] [PubMed]

47. Pereira, H.S.; Delgado, M.; Avó, A.P.; Barão, A.; Serrano, I.; Viegas, W. Pollen Grain Development Is Highly Sensitive to Temperature Stress in Vitis Vinifera. Aust. J. Grape Wine Res. 2014, 20, 474-484. [CrossRef]

48. Giannuzzi, G.; D’Addabbo, P.; Gasparro, M.; Martinelli, M.; Carelli, F.N.; Antonacci, D.; Ventura, M. Analysis of High-Identity Segmental Duplications in the Grapevine Genome. BMC Genom. 2011, 12, 436. [CrossRef]

49. Cardone, M.F.; D’Addabbo, P.; Alkan, C.; Bergamini, C.; Catacchio, C.R.; Anaclerio, F.; Chiatante, G.; Marra, A.; Giannuzzi, G.; Perniola, R. Inter-varietal Structural Variation in Grapevine Genomes. Plant J. 2016, 88, 648-661. [CrossRef]

50. Houel, C.; Bounon, R.; Chaïb, J.; Guichard, C.; Péros, J.-P.; Bacilieri, R.; Dereeper, A.; Canaguier, A.; Lacombe, T.; N’Diaye, A. Patterns of Sequence Polymorphism in the Fleshless Berry Locus in Cultivated and Wild Vitis Vinifera Accessions. BMC Plant Biol. 2010, 10, 284. [CrossRef] [PubMed]

51. Beliveau, B.J.; Joyce, E.F.; Apostolopoulos, N.; Yilmaz, F.; Fonseka, C.Y.; McCole, R.B.; Chang, Y.; Li, J.B.; Senaratne, T.N.; Williams, B.R. Versatile Design and Synthesis Platform for Visualizing Genomes with Oligopaint FISH Probes. Proc. Natl. Acad. Sci. USA 2012, 109, 21301-21306. [CrossRef]

52. Karimi, M.R.; Dehvari, V.; Hajiyan, M. Genetics Diversity of Some Grape Genotypes by ISSR and RAPD Markers. Eur. J. Hortic. Sci. 2011, 76, 201-207.

53. Hameed, U.K.A.; Abdelaziz, K.; El Sherif, N. Genetic Diversity of Grapevine (Vitis vinifera L.) Cultivars in Al-Madinah AlMunawara Based on Molecular Markers and Morphological Traits. Bangladesh J. Plant Taxon. 2020, 27, 113-127. [CrossRef]

54. Dettweiler, E.; Jung, A.; Zyprian, E.; Topfer, R. Grapevine Cultivar Muller-Thurgau and Its True to Type Descent. Vitis 2000, 39, 63-66.

55. Lacombe, T.; Boursiquot, J.-M.; Laucou, V.; Di Vecchi-Staraz, M.; Péros, J.-P.; This, P. Large-Scale Parentage Analysis in an Extended Set of Grapevine Cultivars (Vitis vinifera L.). Theor. Appl. Genet. 2013, 126, 401-414. [CrossRef] 
56. Staraz, M.D.V.; Bandinelli, R.; Boselli, M.; This, P.; Boursiquot, J.-M.; Laucou, V.; Lacombe, T.; Vares, D. Genetic Structuring and Parentage Analysis for Evolutionary Studies in Grapevine: Kin Group and Origin of the Cultivar Sangiovese Revealed. J. Am. Soc. Hortic. Sci. 2007, 132, 514-524. [CrossRef]

57. Calò, A.; Costacurta, A.; Maraš, V.; Meneghetti, S.; Crespan, M. Molecular Correlation of Zinfandel (Primitivo) with Austrian, Croatian, and Hungarian Cultivars and Kratošija, an Additional Synonym. Am. J. Enol. Vitic. 2008, 59, $205-209$.

58. Marsal, G.; Mateo-Sanz, J.M.; Canals, J.M.; Zamora, F.; Fort, F. SSR Analysis of 338 Accessions Planted in Penedès (Spain) Reveals 28 Unreported Molecular Profiles of Vitis vinifera L. Am. J. Enol. Vitic. 2016, 67, 466-470. [CrossRef]

59. Baránková, K.; Sotolář, R.; Baránek, M. Identification of Rare Traditional Grapevine Cultivars Using SSR Markers and Their Geographical Location within the Czech Republic. Czech J. Genet. Plant Breed. 2020, 56, 71-78. [CrossRef]

60. Crespan, M.; Giannetto, S.; Coletta, A.; Antonacci, D. The Parents of'Malvasia Nera Di Brindisi/Lecce'Have Been Discovered. Acta. Hortic. 2006, 827, 239-244.

61. Maul, E.; Sudharma, K.N.; Kecke, S.; Marx, G.; Müller, C.; Audeguin, L.; Boselli, M.; Boursiquot, J.M.; Bucchetti, B.; Cabello, F.; et al. The European Vitis Database (www.Eu-Vitis.De): A Technical Innovation through An Online Uploading And Interactive Modification System. Vitis 2012, 51, 79-85.

62. Lefort, F.; Roubelakis-Angelakis, K.A. The Greek Vitis Database: A Multimedia Web-Backed Genetic Database for Germplasm Management of Vitis Resources in Greece. J. Wine Res. 2000, 11, 233-242. [CrossRef]

63. Frei, A.; Vouillamoz, J.F.; Arnold, C. Swiss Vitis Microsatellite Database. In IX International Conference on Grape Genetics and Breeding. Acta Hortic. 2006, 827, 477-480.

64. Villano, C.; Carputo, D.; Frusciante, L.; Santoro, X.; Aversano, R. Use of SSR and Retrotransposon-Based Markers to Interpret the Population Structure of Native Grapevines from Southern Italy. Mol. Biotechnol. 2014, 56, 1011-1020. [CrossRef]

65. Kim, H.J.; Park, S.H.; Kim, J.H.; Yim, B.; Mun, J.H.; Kim, H.B.; Hur, Y.Y.; Yu, H.J. An efficient strategy for developing genotype identification markers based on simple sequence repeats in grapevine. Hortic. Environ. Biotechnol. 2019, 60, 363-372. [CrossRef]

66. D'Onofrio, C.; Scalabrelli, G. Un Database Viticolo Universale. Italus Hortus. 2008, 17, 328-333.

67. This, P.; Jung, A.; Boccacci, P.; Borrego, J.; Botta, R.; Costantini, L.; Crespan, M.; Dangl, G.S.; Eisenheld, C.; Ferreira-Monteiro, F. Characterization of Oriental Cultivars of Grapevine Using a Reference Allele System of Microsatellite Data and Assignment Test. Theor. Appl. Genet. 2004, 109, 1448-1458. [CrossRef]

68. Reed, G.H.; Wittwer, C.T. Sensitivity and Specificity of Single-Nucleotide Polymorphism Scanning by High-Resolution Melting Analysis. Clin. Chem. 2004, 50, 1748-1754. [CrossRef]

69. di Rienzo, V.; Miazzi, M.M.; Fanelli, V.; Savino, V.; Pollastro, S.; Colucci, F.; Miccolupo, A.; Blanco, A.; Pasqualone, A.; Montemurro, C. An Enhanced Analytical Procedure to Discover Table Grape DNA Adulteration in Industrial Musts. Food Control. 2016, 60, 124-130. [CrossRef]

70. Awad, M.; Mylona, P.V.; Polidoros, A.N. Grapevine Phenological Quantitative Trait SSR Genotyping Using High-Throughput HRM-PCR Analysis. Phyton 2020, 89, 905-923. [CrossRef]

71. Bibi, A.C.; Gonias, E.D.; Doulis, A.G. Genetic Diversity and Structure Analysis Assessed by SSR Markers in a Large Collection of Vitis Cultivars from the Island of Crete, Greece. Biochem. Genet. 2020, 58, 294-321. [CrossRef]

72. Ocaña, J.; Walter, B.; Schellenbaum, P. Stable MSAP Markers for the Distinction of Vitis vinifera Cv Pinot Noir Clones. Mol. Biotechnol. 2013, 55, 236-248. [CrossRef]

73. Oetting, W.S.; Lee, H.K.; Flanders, D.J.; Wiesner, G.L.; Sellers, T.A.; King, R.A. Linkage Analysis with Multiplexed Short Tandem Repeat Polymorphisms Using Infrared Fluorescence and M13 Tailed Primers. Genomics 1995, 30, 450-458. [CrossRef]

74. D'Onofrio, C.; Tumino, G.; Gardiman, M.; Crespan, M.; Bignami, C.; de Palma, L.; Barbagallo, M.G.; Muganu, M.; Morcia, C.; Novello, V.; et al. Parentage atlas of Italian grapevine varieties as inferred from SNP genotyping. Front. Plant Sci. 2021, 11, 2265. [CrossRef] [PubMed]

75. Nebish, A.; Tello, J.; Ferradás, Y.; Aroutiounian, R.; Martínez-Zapater, J.M.; Ibáñez, J. SSR and SNP Genetic Profiling of Armenian Grape Cultivars Gives Insights into Their Identity and Pedigree Relationships. OENO One 2021, 55, 101-114. [CrossRef]

76. De Lorenzis, G.; Chipashvili, R.; Failla, O.; Maghradze, D. Study of Genetic Variability in Vitis vinifera L. Germplasm by High-Throughput Vitis18kSNP Array: The Case of Georgian Genetic Resources. BMC Plant Biol. 2015, 15, 154. [CrossRef] [PubMed]

77. Sunseri, F.; Lupini, A.; Mauceri, A.; De Lorenzis, G.; Araniti, F.; Brancadoro, L.; Dattola, A.; Gullo, G.; Zappia, R.; Mercati, F. Single Nucleotide Polymorphism Profiles Reveal an Admixture Genetic Structure of Grapevine Germplasm from Calabria, Italy, Uncovering Its Key Role for the Diversification of Cultivars in the Mediterranean Basin. Aust. J. Grape Wine Res. 2018, 24, 345-359. [CrossRef]

78. Gambino, G.; Boccacci, P.; Chitarra, W.; Schneider, A.; Rolle, L. Genetic traceability of 'Nebbiolo'musts and wines by single nucleotide polymorphism (SNP) genotyping assays. In Macrowine; IVES: Villenave d'Ornon, France, $2021 ;$ p. 7974.

79. Kunej, U.; Dervishi, A.; Laucou, V.; Jakše, J.; Štajner, N. The Potential of HTS Approaches for Accurate Genotyping in Grapevine (Vitis vinifera L.). Genes 2020, 11, 917. [CrossRef]

80. Scheben, A.; Batley, J.; Edwards, D. Genotyping-by-sequencing Approaches to Characterize Crop Genomes: Choosing the Right Tool for the Right Application. Plant Biotechnol. J. 2017, 15, 149-161. [CrossRef] 
81. Wickland, D.P.; Battu, G.; Hudson, K.A.; Diers, B.W.; Hudson, M.E. A Comparison of Genotyping-by-Sequencing Analysis Methods on Low-Coverage Crop Datasets Shows Advantages of a New Workflow, GB-EaSy. BMC Bioinform. 2017, 18, 586. [CrossRef]

82. Baird, N.A.; Etter, P.D.; Atwood, T.S.; Currey, M.C.; Shiver, A.L.; Lewis, Z.A.; Selker, E.U.; Cresko, W.A.; Johnson, E.A. Rapid SNP Discovery and Genetic Mapping Using Sequenced RAD Markers. PLoS ONE 2008, 3, e3376. [CrossRef]

83. Catchen, J.; Hohenlohe, P.A.; Bassham, S.; Amores, A.; Cresko, W.A. Stacks: An Analysis Tool Set for Population Genomics. Mol. Ecol. 2013, 22, 3124-3140. [CrossRef]

84. Garrison, E.; Marth, G. Haplotype-Based Variant Detection from Short-Read Sequencing. arXiv preprint. arXiv:1207.3907 2012.

85. Rimmer, A. Platypus, a Reference Genome-Free Algorithm That Rapidly Calls Variants in Clinical Sequencing Data. Nat. Genet 2014, 46, 912-918. [CrossRef] [PubMed]

86. McKenna, A.; Hanna, M.; Banks, E.; Sivachenko, A.; Cibulskis, K.; Kernytsky, A.; Garimella, K.; Altshuler, D.; Gabriel, S.; Daly, M. The Genome Analysis Toolkit: A MapReduce Framework for Analyzing next-Generation DNA Sequencing Data. Genome Res. 2010, 20, 1297-1303. [CrossRef] [PubMed]

87. Marrano, A.; Birolo, G.; Prazzoli, M.L.; Lorenzi, S.; Valle, G.; Grando, M.S. SNP-Discovery by RAD-Sequencing in a Germplasm Collection of Wild and Cultivated Grapevines (V. Vinifera L.). PLoS ONE 2017, 12, e0170655. [CrossRef]

88. Potokina, E.K.; Grigoreva, E.A.; Karzhaev, D.S.; Ulianich, P.S.; Volkov, V.A.; Vasylyk, I.A.; Volynkin, V.A.; Likhovskoi, V.V. Genomic Introgressions of Immune Vitis Rotundifola Michx into Russian Grapevine Germplasm Revealed by RADseq Genotyping. In Plant Genetics, Genomics, Bioinformatics, and Biotechnology; Kochetov, A.V., Salina, E.A., Eds.; Institute of Cytology and Genetics, Siberian Branch of the Russian Academy of Sciences: Novosibirsk, Russia, 2021; p. 177.

89. Elshire, R.J.; Glaubitz, J.C.; Sun, Q.; Poland, J.A.; Kawamoto, K.; Buckler, E.S.; Mitchell, S.E. A Robust, Simple Genotyping-bySequencing (GBS) Approach for High Diversity Species. PLoS ONE 2011, 6, e19379.

90. Esposito, S.; Cardi, T.; Campanelli, G.; Sestili, S.; Díez, M.J.; Soler, S.; Jaime, P.; Tripodi, P. ddRAD sequencing-based genotyping for population structure analysis in cultivated tomato provides new insights into the genomic diversity of Mediterranean 'da serbo' type long shelf-life germplasm. Hortic. Res. 2020, 7, 1-14. [CrossRef]

91. Esposito, S.; Carputo, D.; Cardi, T.; Tripodi, P. Applications and Trends of Machine Learning in Genomics and Phenomics for Next-Generation Breeding. Plants 2020, 9, 34. [CrossRef]

92. D'Agostino, N.; Taranto, F.; Camposeo, S.; Mangini, G.; Fanelli, V.; Gadaleta, S.; Miazzi, M.M.; Pavan, S.; di Rienzo, V.; Sabetta, W.; et al. GBS-derived SNP catalogue unveiled wide genetic variability and geographical relationships of Italian olive cultivars. Sci. Rep. 2018, 8, 15877. [CrossRef]

93. Taranto, F.; D'Agostino, N.; Tripodi, P. An overview of genotyping by sequencing in crop species and its application in pepper. Dyn. Math. Models Biol. 2016, 101-116.

94. Calderón, L.; Mauri, N.; Muñoz, C.; Carbonell-Bejerano, P.; Bree, L.; Bergamin, D.; Sola, C.; Gomez-Talquenca, S.; Royo, C.; Ibáñez, J. Whole Genome Resequencing and Custom Genotyping Unveil Clonal Lineages in 'Malbec'Grapevines (Vitis vinifera L.). Sci. Rep. 2021, 11, 7775. [CrossRef]

95. Davey, J.W.; Cezard, T.; Fuentes-Utrilla, P.; Eland, C.; Gharbi, K.; Blaxter, M.L. Special Features of RAD Sequencing Data: Implications for Genotyping. Mol. Ecol. 2013, 22, 3151-3164. [CrossRef]

96. Shafer, A.B.; Peart, C.R.; Tusso, S.; Maayan, I.; Brelsford, A.; Wheat, C.W.; Wolf, J.B. Bioinformatic Processing of RAD-seq Data Dramatically Impacts Downstream Population Genetic Inference. Methods Ecol. Evol. 2017, 8, 907-917. [CrossRef]

97. Jaillon, O.; Aury, J.-M.; Noel, B.; Policriti, A.; Clepet, C.; Cassagrande, A.; Choisne, N.; Aubourg, S.; Vitulo, N.; Jubin, C. The Grapevine Genome Sequence Suggests Ancestral Hexaploidization in Major Angiosperm Phyla. Nature 2007, 449, $463-467$. [PubMed]

98. Velasco, R.; Zharkikh, A.; Troggio, M.; Cartwright, D.A.; Cestaro, A.; Pruss, D.; Pindo, M.; FitzGerald, L.M.; Vezzulli, S.; Reid, J. A High Quality Draft Consensus Sequence of the Genome of a Heterozygous Grapevine Variety. PLoS ONE 2007, 2, e1326. [CrossRef] [PubMed]

99. Adam-Blondon, A.-F.; Martinez-Zapater, J.-M.; Kole, C. Genetics, Genomics, and Breeding of Grapes; CRC Press: Boca Raton, FL, USA, 2016.

100. Canaguier, A.; Grimplet, J.; Di Gaspero, G.; Scalabrin, S.; Duchêne, E.; Choisne, N.; Mohellibi, N.; Guichard, C.; Rombauts, S.; Le Clainche, I. A New Version of the Grapevine Reference Genome Assembly (12X. v2) and of Its Annotation (VCost. V3). Genom. Data 2017, 14, 56. [CrossRef] [PubMed]

101. Liang, Z.; Duan, S.; Sheng, J.; Zhu, S.; Ni, X.; Shao, J.; Mao, R.; Zhu, Y.; Deng, W.; Yang, M.; et al. Whole-genome resequencing of 472 Vitis accessions for grapevine diversity and demographic history analyses. Nat. Commun. 2019, 10, 1190. [CrossRef] [PubMed]

102. Pelsy, F.; Bevilacqua, L.; Blanc, S.; Merdinoglu, D. A Molecular Marker Set Combining a Retrotransposon Insertion and SSR Polymorphisms Is Useful for Assessing Diversity in Vitis. OENO One 2021, 55, 403-414. [CrossRef]

103. Carbonell-Bejerano, P.; Royo, C.; Torres-Pérez, R.; Grimplet, J.; Fernandez, L.; Franco-Zorrilla, J.M.; Lijavetzky, D.; Baroja, E.; Martínez, J.; García-Escudero, E. Catastrophic Unbalanced Genome Rearrangements Cause Somatic Loss of Berry Color in Grapevine. Plant Physiol. 2017, 175, 786-801. [CrossRef]

104. Fuller, C.W.; Middendorf, L.R.; Benner, S.A.; Church, G.M.; Harris, T.; Huang, X.; Jovanovich, S.B.; Nelson, J.R.; Schloss, J.A.; Schwartz, D.C. The Challenges of Sequencing by Synthesis. Nat. Biotechnol. 2009, 27, 1013-1023. [CrossRef] 
105. Mahmoud, M.; Gobet, N.; Cruz-Dávalos, D.I.; Mounier, N.; Dessimoz, C.; Sedlazeck, F.J. Structural Variant Calling: The Long and the Short of It. Genome Biol. 2019, 20,1-14. [CrossRef]

106. Smith, D.R.; Quinlan, A.R.; Peckham, H.E.; Makowsky, K.; Tao, W.; Woolf, B.; Shen, L.; Donahue, W.F.; Tusneem, N.; Stromberg, M.P. Rapid Whole-Genome Mutational Profiling Using next-Generation Sequencing Technologies. Genome Res. 2008, 18, 1638-1642. [CrossRef]

107. Eid, J.A.; Fehr, J.; Gray, K.; Luong, J.; Lyle, G.; Otto, P.; Peluso, P.; Rank, D.; Baybayan, P.; Bettman, B.; et al. Real-time DNA sequencing from single polymerase molecules. Science 2009, 323, 133-138. [CrossRef] [PubMed]

108. Niedringhaus, T.P.; Milanova, D.; Kerby, M.B.; Snyder, M.P.; Barron, A.E. Landscape of Next-Generation Sequencing Technologies. Anal. Chem. 2011, 83, 4327-4341. [CrossRef] [PubMed]

109. Chin, C.-S.; Peluso, P.; Sedlazeck, F.J.; Nattestad, M.; Concepcion, G.T.; Clum, A.; Dunn, C.; O’Malley, R.; Figueroa-Balderas, R.; Morales-Cruz, A. Phased Diploid Genome Assembly with Single-Molecule Real-Time Sequencing. Nat. Methods 2016, 13, 1050-1054. [CrossRef] [PubMed]

110. Minio, A.; Lin, J.; Gaut, B.S.; Cantu, D. How Single Molecule Real-Time Sequencing and Haplotype Phasing Have Enabled Reference-Grade Diploid Genome Assembly of Wine Grapes. Front. Plant Sci. 2017, 8, 826. [CrossRef]

111. Roach, M.J.; Johnson, D.L.; Bohlmann, J.; van Vuuren, H.J.; Jones, S.J.; Pretorius, I.S.; Schmidt, S.A.; Borneman, A.R. Population Sequencing Reveals Clonal Diversity and Ancestral Inbreeding in the Grapevine Cultivar Chardonnay. PLoS Genet. 2018, 14, e1007807. [CrossRef]

112. Weirather, J.L.; de Cesare, M.; Wang, Y.; Piazza, P.; Sebastiano, V.; Wang, X.-J.; Buck, D.; Au, K.F. Comprehensive Comparison of Pacific Biosciences and Oxford Nanopore Technologies and Their Applications to Transcriptome Analysis. F1000Research 2017, 6. [CrossRef]

113. Pucker, B.; Schwandner, A.; Becker, S.; Hausmann, L.; Viehöver, P.; Töpfer, R.; Weisshaar, B.; Holtgräwe, D. RNA-Seq Time Series of Vitis vinifera Bud Development Reveals Correlation of Expression Patterns with the Local Temperature Profile. Plants 2020, 9, 1548. [CrossRef]

114. Khalil-Ur-Rehman, M.; Sun, L.; Li, C.-X.; Faheem, M.; Wang, W.; Tao, J.-M. Comparative RNA-Seq Based Transcriptomic Analysis of Bud Dormancy in Grape. BMC Plant Biol. 2017, 17, 18. [CrossRef]

115. Guo, D.-L.; Xi, F.-F.; Yu, Y.-H.; Zhang, X.-Y.; Zhang, G.-H.; Zhong, G.-Y. Comparative RNA-Seq Profiling of Berry Development between Table Grape ‘Kyoho'and Its Early-Ripening Mutant 'Fengzao'. BMC Genom. 2016, 17, 795.

116. Ma, Q.; Yang, J. Transcriptome profiling and identification of the functional genes involved in berry development and ripening in Vitis vinifera. Gene 2019, 680, 84-96. [CrossRef]

117. Minio, A.; Massonnet, M.; Figueroa-Balderas, R.; Castro, A.; Cantu, D. Diploid Genome Assembly of the Wine Grape Carménère. G3 Genes Genomes Genet. 2019, 9, 1331-1337. [CrossRef] [PubMed]

118. Ghan, R.; Petereit, J.; Tillett, R.L.; Schlauch, K.A.; Toubiana, D.; Fait, A.; Cramer, G.R. The Common Transcriptional Subnetworks of the Grape Berry Skin in the Late Stages of Ripening. BMC Plant Biol. 2017, 17, 94. [CrossRef] [PubMed]

119. Gonçalves, M.F.; Nunes, R.B.; Tilleman, L.; Van de Peer, Y.; Deforce, D.; Van Nieuwerburgh, F.; Esteves, A.C.; Alves, A. Dual RNA Sequencing of Vitis vinifera during Lasiodiplodia Theobromae Infection Unveils Host-Pathogen Interactions. Int. J. Mol. Sci. 2019, 20, 6083. [CrossRef] [PubMed]

120. Toffolatti, S.L.; De Lorenzis, G.; Brilli, M.; Moser, M.; Shariati, V.; Tavakol, E.; Maddalena, G.; Passera, A.; Casati, P.; Pindo, M. Novel Aspects on the Interaction between Grapevine and Plasmopara Viticola: Dual-RNA-Seq Analysis Highlights Gene Expression Dynamics in the Pathogen and the Plant during the Battle for Infection. Genes 2020, 11, 261. [CrossRef]

121. Sidharthan, V.K.; Sevanthi, A.M.; Jaiswal, S.; Baranwal, V.K. Robust Virome Profiling and Whole Genome Reconstruction of Viruses and Viroids Enabled by Use of Available MRNA and SRNA-Seq Datasets in Grapevine (Vitis vinifera L.). Front. Microbiol. 2020, 11, 1232. [CrossRef]

122. Cirulli, E.T.; Goldstein, D.B. Uncovering the Roles of Rare Variants in Common Disease through Whole-Genome Sequencing. Nat. Rev. Genet. 2010, 11, 415-425. [CrossRef]

123. Guo, Y.; Yu, H.; Samuels, D.C.; Yue, W.; Ness, S.; Zhao, Y. Single-Nucleotide Variants in Human RNA: RNA Editing and Beyond. Brief. Funct. Genom. 2019, 18, 30-39. [CrossRef]

124. Royo, C.; Torres-Pérez, R.; Mauri, N.; Diestro, N.; Cabezas, J.A.; Marchal, C.; Lacombe, T.; Ibáñez, J.; Tornel, M.; Carreño, J. The Major Origin of Seedless Grapes Is Associated with a Missense Mutation in the MADS-Box Gene VviAGL11. Plant Physiol. 2018, 177, 1234-1253. [CrossRef]

125. Zenoni, S.; Ferrarini, A.; Giacomelli, E.; Xumerle, L.; Fasoli, M.; Malerba, G.; Bellin, D.; Pezzotti, M.; Delledonne, M. Characterization of transcriptional complexity during berry development in Vitis vinifera using RNA-Seq. Plant Physiol. 2010, 152, 1787-1795. [CrossRef]

126. Royo, C.; Carbonell-Bejerano, P.; Torres-Pérez, R.; Nebish, A.; Martínez, Ó.; Rey, M.; Aroutiounian, R.; Ibáñez, J.; Martínez-Zapater, J.M. Developmental, Transcriptome, and Genetic Alterations Associated with Parthenocarpy in the Grapevine Seedless Somatic Variant Corinto Bianco. J. Exp. Bot. 2016, 67, 259-273. [CrossRef] 
127. Wang, R.; Xue, Y.; Fan, J.; Yao, J.-L.; Qin, M.; Lin, T.; Lian, Q.; Zhang, M.; Li, X.; Li, J. A Systems Genetics Approach Reveals PbrNSC as a Regulator of Lignin and Cellulose Biosynthesis in Stone Cells of Pear Fruit. Genome Biol. 2021, 22, 1-23. [CrossRef] [PubMed]

128. Piskol, R.; Ramaswami, G.; Li, J.B. Reliable Identification of Genomic Variants from RNA-Seq Data. Am. J. Hum. Genet. 2013, 93, 641-651. [CrossRef] [PubMed] 